\title{
Recognition of New Interests in the Law of Torts
}

$\mathrm{H}$ ISTORICALLY, the process of giving recognition to the claims, wants, and demands of individuals as subjects of rights was first by writ or remedy, next by admitting certain rights, and lastly by recognizing certain interests. Under this method, if there was no appropriate remedy, there could be no legal right, however pressing the claim might be, morally, for recognition by the law. In such case, where the law itself did not grant relief, either self-help or the help of the gods provided practically the only method of redress. Only slowly, through extension of writs and remedies, and by the enforcement of duties, by the praetors in Roman Law and by the chancellors in English Equity, did first duties arise, and then legal rights, resulting consequently in independence of the methods of enforcement; yet considerable time elapsed before the final step was taken, namely, to recognize the interest, which existed apart from the law, and then to elevate this into a legal right, protected by the proper legal remedy.

The stage of development from remedy to interest is clearly seen both in the Roman and in the cominon law. In the primitive law, when the state was weak, self-help or help of the gods, to secure protection of the interests of individuals, was largely relied upon. So in the Roman Law the creditor might bring. the debtor into court through force, by the legis actio per manus injectionem; or he might himself seize the goods of the debtor who failed to pay his debt, by the legis actio per pignoris capionem. ${ }^{1}$ Elaborate provisions, therefore, in both the Roman and the common law, grew up with respect to self-help, as recapture of chattels from a thief on fresh pursuit; re-entry on land of which one had been forcibly dispossessed; defense of one's person or nearest relatives; abatement of nuisance where there was no opportunity to apply

1 Sohm, Institutes of Roman Law, 3d ed., 229; Pound, Readings in Romau Law, 88.

"It is not at all certain that the legis actio per pignoris capionem is a vestige of self-help, although so given by some writers on Roman Law. Nevertheless, in view of the fact that the lex Julia de $V i$ forbade forcible enforcement of debts by the creditor, imposing severe penalties upon the creditor, it has been placed among the actions of self-help; but the action was from early times confined in narrow limits. See Girard, Manuel Elementaire de Droit Romain, 3d ed., 971.” 
to the magistrate, etc. Some of these have persisted to the present time. ${ }^{2}$ Gradually, however, as the state increased in power and the usual mode of redress of one's rights was by means of the political organization or the state, tariffs of compositions were enacted, which provided a specific penalty for the violation of those most obvious interests which a rude community naturally had. This made the law definitely predicable and at the same time prevented dispute between litigants, for argument, it was believed, night lead to private warfare that must by all means be averted. However, if no composition was provided by the law, the injured party was without relief.

The Strict Law, which succeeded the former -stage of the primitive law, realized in a measure the injustice of the older method of composition, and substituted an elaborate system of remedies, making one's legal rights depend upon the remedy which might be available. The next stage in the law, that of Equity and Natural Law, attempted to improve on the previous period by recoguizing certain moral duties which the legal remedy protected. The period of the Maturity of Law went one step further and recognized that corresponding to every duty there was a correlative right which would be protected by the law. ${ }^{3}$

Logically, the process for inaking the law effective as a means of realizing justice requires a reversal of the historical method of remedy, duty, right, and interest. Today, thanks to the insistence of Rudolf Jhering ${ }^{4}$ and the sociological school of jurists, the legal system approaches the problem of the administration of justice by an inductive, instead of a deductive, process. The problem today is, What are the interests, individual and social, which the law should recoguize, in order that the law may serve its purpose of furthering civilization? Once it was believed that the highest good lay in a maximum of individual liberty; today we attempt to satisfy the most needs with the least sacrifice of others, in order that the individual may live a full, a richer, moral life. After these interests have once been recognized by the law, or after their invisible boundaries have been determined, in the words

2 German Civil Code, \$§227-231, 859; Dernburg, Pandekten, I, §112; Cosack, Lehrbuch des deutschen burgerlichen Rechts, I, \$ 78; Windscheid, Lehrbuch, I. \$ 83; Bowler v. Eldredge (1846) 18 Conn. 1; Spencer v. McGowan (1835) 13 Wend. 256; Moore v. Shenk (1846) 3 Pa. St. 1.

3 Roscoe Pound, "The End of Law as Developed in Legal Rules and Doctrines," 27 Harvard Law Review, 195, 224.

4 Der Zweck im Recht, I, Preface; ch. 1, §1; ch. 3, §5; Scherz und Ernst, in der Jurisprudenz, 10th ed., 245-251. 
of Savigny, the law then makes them into legal rights, and gives protection to them through legal remedies. These interests which individuals may have, corresponding to the old "natural rights" of our forefathers, must not be thought of as static, not subject to change with new and different conditions. On the contrary, they are subject to fluctuation, due to changed environmental conditions and to more adequate and effective means of enforcement by the judicial machinery. Sir Henry Maine tells us that with the inauguration of the British system of law and courts into India, the natives became conscious of "rights" or interests which they never before realized. On the other hand, many interests which were thought to be indispensable in the past have today become unimportant, as, for instance, the so-called "right" to bear arms, of which the fathers of the constitution were so solicitous; while again, new interests not contemplated by the past have, with enlarged knowledge, come into recognition by the law.

Recently, particularly in the field of torts, the law has been gradually moving cautiously forward in giving legal effect to interests which in times past were not recognized. Some courts today are recognizing that the injury is the primary and paramount consideration, not the character of the defendant who inflicts it, nor the nature of the act itself. If causation and injury can be established, and the defendant acted wrongfully, the law will give a remedy. Such is the case, particularly, in permitting recovery for pre-natal injuries; giving the wife tort actions against the husband; allowing recovery for mental suffering; and permitting tort actions against municipal corporations in the face of ancient doctrines which exempted them from liability. These different situations, where the injury and not the character of the defendant or the nature of the act is emphasized, will be taken up in order.

\section{Recovery for Pre-Natal Injuries}

Until fairly recently, no one could find any decisions by American and British courts which permitted a tort action for injuries to the infant en ventre sa mere.5 The reason was, largely, that

5 "We have not been able to find any precedent at common law establishing the right of a child, injured while en ventre sa mere, but subsequently born alive, to bring an action thereafter for the injuries so received .... although there must have been many occasions in the progress of society when a basis existed for such a suit, if it had been thought to be maintainable." Buel v. United Railways Co. (1913) 248 Mo. 126, 154 S. W. 71; so also Allaire v. St. Luke's Hospital (1900) 56 N. E. (III.) 638. 
the law held the child had no legal personality at the time the injury to the mother, and through her to the child, occurred. Even though the causal connection between defendant's wrongful act and the injury to the unborn child was not in question, or was admitted, the courts refused to grant relief, either to the child itself after it had been born alive, or to its administrator in case the child later died as a result of the tort to the mother. Wherever judges did admit, for some purposes, that the child was a person while still unborn, they either rejected the idea that it was a person to maintain tort actions, or, while admitting its personality, they feared the consequences of such a doctrine were it once admitted into the law. ${ }^{6}$

In the Roman Law, the doctrine with reference to pre-natal injuries was stated to be that the infant would be protected as if alive, wherever the advantage of the offspring itself was in question.7 Moreover, statutory inheritances were given the unborn child; and if a pregnant woman were captured by the enemy, the child when born would have the right of post-liminium; also a curator might be appointed for the unborn infant. ${ }^{8}$ But the modern civil law, especially in Germany and France, has not extended legal personality to the infant en ventre sa mere.

In the Old Testament there were provisions inade by the law

6 "On what a boundless sea of speculation in evidence this new idea [of permitting recovery, for pre-natal injuries] would launch us." O'Brien, J., in Walker v. Great Northern Railway Co. (1890) 28 L. R. (Ir.) 69.

7 "He who is in the womb shall be protected as' if alive wherever the advantage of the offspring itself is in question; but there shall be no advantage to others before he is born." Digest, $I, 5,7$. "What we have said, that he whose birth is expected is held for alive, is true when the question is concerning his own right; but he cannot be of advantage to others unless born." Digest, L, 16, 231 .

"As far as the actual nasciturus itself was concerned, there is a definite and unequivocal statement in the sources which repudiates the suggestion that it is a person in any sense. This is to be found in Ulpian, Dig. 25, 4, 1, 1: 'Partus enim antequam edatur mulieris portio est vel viscerum.' This is merely a statement of the Stoic view on the subject which was generally accepted. In fact, abortion, though widely practised, was not made criminal in Ronian Law until nearly $200 \mathrm{~A}$. D., and then it was not thought of as homicide. I am indebted to Professor Radin for observations on this topic."

8 Digest, I, 5, 26; XXVI, 5, 20.

9 "The capacity of a human being for rights begins with the conıletion of birth." German Civil Code, §1, also art. 844; 1 Planiol, Droit Civil, 8 ed., \$\$ 365-367. The Swiss Civil Code, art. 31, provides: "Personality begins with the completed birth of a living child; it is ended by death. A child conceived enjoys civil rights, provided it be born alive." "A natural person exists when a human being $(1)$ is fully severed from the body of a mother, and also (2) living, (3) of human shape, (4) developed." Baron, Pandekten, § 18. See also Dernburg, Pandekten, I, § 40, 3. 
with respect to injuries committed to unborn children. In Exodus $\mathrm{xxi}: 22-25$; it is said :

"If men strive, and hurt a woman with child, so that her fruit depart from her, and yet no mischief follow: he shall be surely punished, according as the woman's husband will lay upon him; and he shall pay as the judges determine. And if any mischief follow, then thou shalt give life for life. Eye for eye, tooth for tooth, hand for hand, foot for foot; burning for burning, wound for wound, stripe for stripe."10

As already stated, however, the common law until recently has not permitted the unborn child any standing in court to redress any tort committed to it, even though later born alive. The earliest case involving tort action for pre-natal injuries appears to be Dietrich v. Northampton, ${ }^{11}$ decided in 1884 . In this case a woman four or five months advanced in pregnancy slipped and fell because of a defect in the highway, as a result of which there was a miscarriage. Though the child was alive when delivered, it was too little advanced in foetal life to survive its premature birth, and died before it was severed from its mother. It was held that the action did not accrue to the infant's administrator. In Walker v. Great Northern Railway Company, ${ }^{12}$ the next case, decided in 1890, a pregnant woman was injured while a passenger on defendant's train, in such a manner as to permanently wound and cripple plaintiff, then en ventre sa mere. The case was decided primarily on the fact that there was no contract relation between defendant and plaintiff to carry safely, as the defendant did not know plaintiff was in existence. The justices were in much hesitation as to the bare question whether, apart from the absence of a relation of carrier and passenger, plaintiff should be allowed to recover. In 1900 the case of Allaire v. St. Luke's Hospital ${ }^{13}$ was decided. In this case, plaintiff's mother, about ten days before it was expected she would be confined, went to defendant's hospital for treatment and care during her accouchement. While in the hospital, she was negligently injured in an elevator operated by defendant's servant, so that plaintiff, who was born four days

10 "By most commentators, the 'mischief' referred to means injury to the woman, not to the child; and the Code of Hammurabi, sections 209-211, contains similar references. It is noticeable, however, that even if no mischief or injury occurred to the wife by reason of the miscarriage caused by the wrongful act of the defendant, the latter was to be punished nevertheless."

11 (1884) 138 Mass. 14, 52 Am. Rep. 242.

12 (1890) 28 L. R. (Ir.) 69.

13 (1900) 184 Ill. 359, 56 N. E. 638, 48 L. R. A. 225, 75 Am. St. Rep. 176. 
afterward, was also severely injured. The court in its opinion strongly reacted against allowing the infant to recover, saying that the doctrine of the civil law, in the early ecclesiastical and admiralty courts, which permitted actions by infants when to their advantage, was purely a legal fiction which had never been indulged in by the common-law courts, and which, if it were followed, would also permit the infant to sue its mother in case the latter had been negligent. In 1901, the Supreme Court of Rhode Island, in Gorman v. Budlong, ${ }^{14}$ likewise refused recovery to the infant en ventre sa mere. There, through negligence of the landlord, the ceiling fell upon a tenant with an unborn child, whereby a premature birth and subsequent death of the child ensued. The court held that, since the child itself could not have any right of action, none survived to its next of kin under the death statute. ${ }^{15}$ In Nugent v. Brooklyn Heights Railway Company, ${ }^{16}$ decided in 1913 , plaintiff was an unborn infant, who was injured thirty-six days before his birth, by reason of the negligence of the defendant railroad. At the time of the injury, the mother was alighting from defendant's car. The opinion, by Mr. Justice Thomas, is very illuminating. Although, as in the Great Northern Railway case, supra, recovery was denied, on the ground that there was no contract relation between defendant and plaintiff, the court admits the many purposes for which the unborn child is considered in the common law as being in existence, and intimates there may be instances where the infant en ventre sa mere may recover for personal injuries. With reference to the argument that the unborn infant's property rights may be validly recognized by the law, but not tort actions to his person, Mr. Justice Thomas remarks:

"But the argument then proceeds that one inust respect the rights of ownership, and, so far as a civil remedy is concerned, disregard the safety of the owner. In such argument there is not true sense of proportion in the protection of rights. The greater is denied; the lesser one, and dependent on the very existence of a person in esse and entitled to protection, is respected." (p. 282.)

In 1913 the Supreme Court of Missouri, in Buel v. United Railways Company, ${ }^{17}$ joined the jurisdictions which deny recovery

14 (1901) 23 R. I. 169, 49 At1. 704.

15 Note, "Legal Protection to Unborn Children," 15 Harvard Law Review, 313 .

18 (1913) 154 App. Div. 667, 139 N. Y. Supp. 367.

17 (1913) 248 Mo. 126, 154 S. W. 71. 
for pre-natal injuries. Plaintiffs were father and mother. While the mother was enceinte of the unborn child, she became a passenger on defendant's street railway. In alighting from the car, she was negligently thrown to the ground, sustaining injuries which likewise were communicated to the unborn infant. Though the child was born alive some three months later, it lived only some six months. A statute provided for the recovery by next of kin for death for wrongful act, but the court refused relief, basing its decision largely upon the precedents which denied relief. ${ }^{18}$ Apparently, these are the only cases to be found in the American and English decisions which deal with the question of pre-natal injuries, and all deny relief.

But recently, a case ${ }^{19}$ decided by the Appellate Division in New York, only two justices dissenting, permitted recovery by an infant en ventre sa mere, where its mother had been ijured, and so the infant, through the negligence of defendant in leaving a coal-hole unguarded. The plaintiff was born eleven days later and brought suit by guardian ad litem. Mr. Justice Merrell, in rendering the opinion permitting recovery, states that "the great weight of authority has established that, for all purposes beneficial to the infant after his birth, an infant en ventre sa mere shall be considered to be born." (p. 279.) Just what are the "beneficial purposes" for which the unborn infant has been treated as a distinct person while unborn; though later born alive? The following instances may be noted:

1. The infant en ventre sa mere may inherit property, either by descent or devise, and take generally under the statutes of distribution. ${ }^{20}$ In the rule against perpetuities, the infant in utero

18 A previous case in Missouri, Kirk v. Middlebrook (1906) 201 Mo. 285, $100 \mathrm{~S}$. W. 450 , had likewise held that injuries to a quick child about to be born, must be taken to be held as done to the mother, unless the injuries had been done actually and directly to the child with the forceps of the accoucheur.

${ }^{10}$ Drobner v. Peters (1921) 194 App. Div. 696, 186 N. Y. Supp. 278. Reversed by the court of appeals of New York, (1921) 232 N. Y. 220, 133 N. E. 567 .

20 In Thellusson v. Woodford (1798) 4 Ves. Jr. 322, 31 Eng. Rep. Reprint 117, where it was decided that an executory devise limited after seven lives in being and that of an unborn child was not repugnant to the rule against perpetuities, Justice Buller said: "Let us see what this nonentity can do. He may be vouched in a recovery, though it is for the purpose of making him answer over in value. He may be named executor. He may take under the statute of distributions. He may take by devise. $\mathrm{He}$ may be entitled under a charge for arresting persons. He may have an injunction, and he may have a gnardian." 
is regarded as being in existence; and generally, if it is to the infant's disadvantage, an infant unborn will not be considered as in esse. ${ }^{21}$

2. In the criminal law, the infant is considered in existence though not yet separated from his mother, and hence may be the subject of homicide and manslaughter, although not murder, unless clearly mens rea be shown.22

3. Under Lord Campbell's Act (9 and 10 Vict. c. 93), the infant en ventre sa mere is regarded as capable, when born, of maintaining an action for the death of its parent or next of kin..$^{2 s}$

Inasmuch as our common law has gone thus far in ascribing legal personality to the unborn infant, why should it not, under certain qualifications, likewise give a remedy to the child if, through the defendant's negligence, it has sustamed personal imjuries? It is interesting to observe in this connection that, though the Japanese code is modeled closely upon the German civil code, the former has not followed the German law as to the time when legal personality begins. On the contrary, the Japanese code gives

21 In Villar v. Gilbey [1907] A. C. 139, a testator devised an estate to A for life, remainder to A's third, fourth, and every other son successively in tail, but added a proviso that the third or any later son "born in my lifetime" should take only a life estate with remainders over. At the testator's death, A's third son was en ventre sa mere, and it was held that he took an estate tail, the court refusing to consider him born where it was not to his advantage. See also In re Wilmer (1903) 47 Sol. Jour. 336; Doe d. Clarke v. Clarke (1795) 2 H. Blk. 399, 126 Eng. Rep. Reprint 617; In re Burrows [1895] 2 Ch. 497 . Cf. Blasson v. Blasson (1867) 2 De G. J. \& S. 665, 96 Eng. Rep. Reprint 534; Humbertson v. Humbertson (1716) 1 P. Wms. 332, 24 Eng. Rep. Reprint 412.

${ }_{22}$ "For if a woman is quick with child, and by a potion or otherwise killeth it in her womb; or if any one beat her whereby the child dieth in her body, and she is delivered of a dead child; this, though not murder, was by the ancient law homicide or manslaughter." 1 Blackstone's Commentaries 130. "If a woman be quick or great with child, if she takes, or another gives her, any potion to make an abortion, or if a man strikes her, whereby the child within her is killed, it is not murder nor manslaughter by the law of England, because it is not yet in rerum natura; tho it be a great crime and by the judicial law of Moses was punishable with death." I Hale's Plcas of the Crown, 433. In Rex v. Senior, 1 Moody's C. C. 346, defendant was held guilty of murder, where he maliciously gave an unborn child a mortal wound on the head while assisting the inother in childbirth. "2s "A child unborn at the time of his father's dcath, but later born alive, is to be considered under our laws as an existing person at the time of his father's death, and therefore a beneficiary and entitled to participate under the statute in any recovery of damages for the wrongful death of the father." Herdon v. St. Louis \& S. F. Ry. (1912) 37 Ok1. 256, 128 Pac. 72\%. See also The George \& Richard (1871) 2 I. R. Adm. 466; Quinlen v. Welch (1893) 69 Hun. 584, 23 N. Y. Supp. 963; Galveston v. Contreras (1903) 31 Tex. Civ. App. 489, 72 S. W. 1051; Note, "Legal Protection to Unborn Children," 15 Harvard Law Review, 313 . 
the unborn infant a right of recovery in all cases where it has sustained injury or loss through another's wrongful act. It provides briefly:

"A child en ventre sa mere is regarded as already born with regard to the right of claiming compensation for damage." Japanese Civil Code, Art. 721 (De Becker's Translation.)

What should, therefore, be the rule as to pre-natal torts? Can it be maintained that immediately after conception, whether the infant later is born alive or not, the infant in utero is a legal person? At least in our system of law, where the jury plays such a large role in the determination of fact, we must return a negative answer to such a broad question, largely because the difficulty of proving the causal connection between the wrongful act and the injury is too great, and too remote. Furthermore, there would be great danger of imposition and fraud practiced upon judicial tribunals to permit recovery, in such instances. Here, as well as elsewhere in the law where human conduct is concerned, the various interests, individual and social, must be balanced and weighed. The infant's interest in bodily integrity, or his claim to be born free from deformity, with the attendant claim to a life as full and complete as that of other fellow human beings, undoubtedly makes a powerful appeal to all persons, courts as well as private citizens. On the other hand, in view of the fact that, even though injury and causal connection have been proved, it is yet uncertain whether the child will be born alive, a right of action is sought to be created which is contingent on a subsequent irrelevant fact.

But admitting it to be possible, medically, to prove that the wrongful act caused injury to an unborn child-which today with better scientific knowledge is perhaps easier than in ancient daysis it possible to lay down any criterion for permitting recovery which will succeed, better than in the past, in reaching a more just result? Dernburg, commenting on the Roman and civil law rules, ${ }^{24}$ that a child in utero was for many purposes thought of as being already born, seeks to qualify the rule as follows:

"The moderns express this [rule] by the maxim nasciturus pro iam nacto habetur. But this fiction is limited by the purpose which called it forth. It obtains only in case the embryo later becomes a subject of rights, and if it comes into the world dead or as an abortion, the fiction does not furnish a ground

24 Pandekten, I, § 40, 3. 
for any right of a third person, such as the mother, for example."

A somewhat similar criterion is advanced by. Mr. Justice Boggs, in his dissenting opinion in Allaire v. St. Luke's Hospital, supra, which had denied recovery to the unborn infant, although later it was born alive. Justice Boggs, while admitting that a foetus in the womb of the mother may well be regarded as but a part of the mother during a period of gestation, believes there may be instances where the infant has so far developed as to lead the law to hold it a separate person. His criterion is as follows:

"If, while in the womb, it reaches that pre-natal age of viability when the destruction of the life of the mother does not necessarily end its existence also, and when, if separated prematurely and by artificial means froin the mother, it would be so far a matured human being as that it would live and grow, mentally and physically, as other children generally, it is but to deny a palpable fact to argue there is but one life, and that the life of the mother." (56 N. E. 641.)

It is submitted that this principle is sound, provided of course that causal connection between the wrongful act and the infant's injury be proved. A case decided in 1916 by the Supreme Court of Wisconsin ${ }^{25}$ impliedly favors the criterion laid down by Mr. Justice Boggs and by Dernburg. In that case, plaintiff sustained injuries while a foetus en ventre sa mere of the age of about five months, and before she could have been born viable. Plaintiff's father and mother settled with defendant for the damage sustained by them. After plaintiff was born, she suffered from epileptic fits as a direct result of the pre-natal injuries received. The court, Mr. Justice Vinje delivering the opinion, after reviewing the cases on the subject, which were admitted to be few, refused rehef; but Justice Vinje placed his decision expressly on the ground that it was because plaintiff could not have been born viable at the time the injury occurred, and must consequently be regarded as but a part of its mother at the time of the injury, not having separate legal personality.

It is difficult to see why the law should not keep abreast with the discoveries and advancements of medical science, which make proof of such injuries easier than formerly. Furthermore, if the infant is actually born alive after the injury, showing the visible marks of its injuries or deformity, a yet stronger case is made

25 Lipps y. Milwaukee Electric Ry. \& Light Co. (1916) 164 Wis. 272, 159 N. W. 916. 
out, precluding fraud or doubt that the infant was alive at the time the injury occurred. Again it must be emphasized that it is the injury which is the primary and paramount consideration, and wherever an injury has been sustained the law should give a remedy.

\section{Tort Actrons by Wife Against Husband}

In this field of interests, the law is likewise slowly but cautiously advancing in recognizing certain claims of the wife for torts committed against her by the husband. Of course, at common law, it was impossible, because of the unity of husband and wife, for the latter to sue the husband at law for torts, and in this particular instance the husband likewise had no remedy against his wife. ${ }^{28}$ Where this doctrine of unity of husband with his wife originated, is doubtful. By some it has been attributed to the statement of Adam, in Genesis, that after creation of woman from his rib, ${ }^{27}$ he said: "This is now bone of my bones, and flesh of my flesh"; and to the similar statement in Ephesians, ${ }^{28}$ "they two shall be one flesh." Others have referred the origin of the unity of husband and wife to Paul's statement that the wife should be in subjection to the husband; and to his teaching that marriage signified the mystical union that exists between Jesus Christ and his church. ${ }^{29}$ Again, some jurists have believed, though without adequate proof, that because certain early English juristic writers made so inuch use of Roman Law analogies in other fields of the common law the doctrine had its origin in the Roman Law, where the wife was in the manu of her husband, and had no separate legal personality of her own..$^{30}$ Hence, at common law, wherever the wife in justice ought to have had an action against her husband, as for assault and battery, false imprisonment, commitment to an insane asylum wrongfully, it was said by the courts that the privacy of the home was far weightier

26 Stewart, Husband and Wife, §48; Phillips v. Barnet (1876) L. R. 1 Q. B. D. 436; Freethy v. Freethy (1865) 42 Barb. (N. Y.) 641 ; Schultz v. Schultz (1882) 89 N. Y. 644; Thompson v. Thompson (1910) 218 U. S. 611; Peters v. Peters (1876) 42 Iowa 182.

27 Genesis ii :23-24.

28 Genesis v:31.

29 Ephesians $5: 22-24$.

30 For the Roman Law, see Sohm, Institutes of Roman Law, 3d ed., 459 et seq.; Maine, Ancient Law, chap. 5; Fustel de Coulanges, Ancient City, bk. 2, ch. 7; Hearn, Aryan Houschold, chap. 4; Kuhlenbeck, Entwickelungsgeschichte des romischen Rechts, I, 40-45; Jhering, Geist des romischen Rechts, II (5 ed.) 156-218. 
than the individual claims of the wife; hence it was better "to draw the curtain, shut out the public gaze, and leave the parties to forget and forgive. ${ }^{31}$ Of course, if the husband's wrongful acts became too grievous, the wife might bring a criminal indictment against him, and, somewhat later, have relief by a bill of divorce. But for centuries she was without remedy.

Beginning with the middle of the nineteenth century, in the common law countries the status of the married woman was sought to be fundamentally changed. Legal personality was conferred upon her at first partially, and later more fully. One is reminded of a similar development in the Roman Law as to the enlargement, due to conferring of legal personality, of the wife's powers and privileges. $^{32}$ Originating in doctrines of courts of equity, which protected the wife in contracts and property rights with the husband, the legislation finally resulted in complete emancipation of the married woman. But the courts, under the belief that common-law incapacities were natural ones, opposed in their opinions much of this beneficent legislation, just as they did with reference to codes of procedure which sought to remove procedural archaisms from the law. As a consequence, according to the predilection of the judges themselves, our decisions today with respect to permitting the wife, under liberal statutes, to have tort actions against the husband are in conflict. A few courts, however, refusing to inject personal ideas of public policy into their decisions, have reached results more in accord with the spirit of the new legislation regarding married women.

A recent case, illustrating the more liberal tendency to permit tort actions by wife against husband, is Crowell v. Crowell, ${ }^{33}$ decided in 1920 by the Supreme Court of North Carolina. There the husband, through immoral relationships, had contracted a venereal disease and had communicated it to his wife. The

31 State v. Oliver (1874) 70 N. C. $60,61$.

32 Professor Radin and other Roman law jurists hold that the forces which broke down the marriage with manus arose from the dotal system, in that the woman's family was naturally reluctant to surrender its contingent rights to the dos which was considered as an advance of her share of the family inheritance. Certainly, in the days when the ancestral religion was predominant, marriage with manus was a mark of family distinction, confined to patricians, so that other forms of marriage-like usus and coemptio-arose for the plebeians. It is at least conjectural whether the marriage ex jure gentium, without manus (sine manu) had any influence on breaking down the marriage with manus.

83 (1920) 105 S. E. 206 (N. C.). 
statute of North Carolina, ${ }^{34}$ with respect to suits by married women, provided:

"The earnings of a-married woman by virtue of any contract for her personal services and any damages for personal injuries, or other torts sustained by her, can be recovered by her suing alone, and such earnings or recovery shall be her sole and separate property as fully as if she had remained unmarried."

The opinion of Chief Justice Clark, after calling attention to the fact that the unity of husband and wife was now an exploded doctrine and that wives were no longer chattels, granted recovery in the tort action. A concurring opimion, by Mr. Justice Allen, was based upon the wife's property right in her earnings, which it was said would be impaired by the disease which the wife had contracted from the husband. The dissenting opinions followed the orthodox line of reasoning, that no express power was given the wife to sue the husband for personal torts.

It will be instructive to note a number of other equally liberal opinions, handed down comparatively recently. In Fiedeer v. Fiedeer, ${ }^{35}$ the wife after divorce brought an action against her forner husband for injuries received from a gunshot wound maliciously inflicted by the husband during coverture. The Oklahoma statute provided, in substance, that the wife should retain the same legal existence and legal personality after marriage as before marriage. The Supreine Court of Oklahoma, in granting relief to the wife, said it failed to see the philosophy of those courts which permitted the wife to bring a criminal action or a bill of divorce and alimony against the husband, and yet denied an action of tort, especially where the injury was so serious as in the instant case, incapacitating the wife in her earning power. Nor could the court understand how the sensitive nerves of society could be worse jarred in this proceeding than in a divorce suit, which would lay bare every act of their marriage relation.

In Johnson v. Johnson ${ }^{38}$ the wife brought an action against her husband for assault and battery. Under the statutes of Alabama, the wife might have full capacity to contract as if she were a feme sole; husband and wife could contract with each other; and all damages to which the wife might be entitled, in recovering for injuries to her person or reputation, were to be her separate

34 Laws, 1913, ch. 13, \&1.

85 (1914) 140 Pac. 1022 (Okla.).

86 (1918) 77 So. 335 (Ala.). 
property..$^{37}$ Section 4493 provided in substance that the wife should sue alone for injuries to such property as was her own, and "for all injuries to her person or reputation." The court, after deciding that the Alabama statute had abolished the legal unity of husband and wife, and after pointing out that actions involving the wife's property had already been brought against the husband, ${ }^{38}$ allowed the wife to inaintain the action for assault and battery.9.

The Supreme Court of South Carolina, in Prosser v. Prosser,40 reached a very liberal result under statutes which, without expressly mentioning married women, gave to all persons generally tort actions for wrongs committed against thein. The Act of 1870 provided that to redress a private wrong action inust be brought by the real party in interest (sec. 160), and previous constitutions of South Carolina, those of 1868 and 1870, had given the wife power to hold property and to contract as if she were unmarried. In the Prosser case, the wife sued her husband in tort for wilfully beating her. The court permitted recovery, not simply because she was the real party in interest within the ineaning of the statute of 1870 , but also because a suit for a wrong to her person was a chose in action, or property belonging to her, and for this she could sue her husband.

In 1915 the Supreme Court of New Hampshire decided the case of Gilman v. Gilman,; ${ }^{11}$ which likewise followed the more liberal tendency of permitting the wife to sue the husband in tort. Section 2, chapter 176, of the Public Statutes provided substantially that a married woman might sue in all matters in law and equity, and upon any contract by her made, or for any wrong by her done, as if she were unmarried. The court, in granting her relief, said:

37 Alabama Code, $\$$ 4492, 4497, 4489.

38 In Bruce v. Bruce (1892) 95 Ala. 563,11 So. 197, the wife was allowed to sue the husband in detinue; and in Cook v. Cook (1900) 125 Ala. 583, 27 So. 918, the wife maintained against the husband an action for the recovery of real estate.

${ }^{30}$ In Johnson v. Johnson, supra, the court said: "The wife's remedies, by a criminal prosecution or an action for divorce and alimony, which in some jurisdictions are allowed to stand as her adequate remedies for wrongs of the sort described in this complaint, so far from being adequate remedies, appear to us to be illusory and inadequate, while, as for the policy which would avoid the public airing of family troubles, we see no reason why it should weigh more heavily against this action than against those which the courts universally allow." P. 338 .

40 (1920) 102 S. E. 787 (S. C.).

11 (1915) 95 Atl. 657 (N. H.). 
"The test to determine whether plaintiff can maintain this action is to inquire whether she could maintain it if she were unmarried, and not to inquire who the defendant is, nor whether she is seeking to enforce a property right."

In Fitzpatrick v. Owens ${ }^{42}$ the Supreme Court of Arkansas granted an action against the husband for torts committed on his wife during coverture. The parties had been divorced a mensa et thoro, and while this relation existed, the husband made a felonious assault upon the wife and killed her. The question was whether the wife's personal representative might bring an action against the husband under the death statute. The Arkansas court had previously held, in Davis v. Railway, ${ }^{48}$ that if the injured party himself had had no cause of action, none would survive to his next of kin or personal representative. It was therefore necessary to determine whether the wife in her lifetime would have had such an action against her husband, and it was decided that she had, under the statute which gave her all the rights of a feme sole."4

The leading case denying to the wife a tort action against her husband, at least for personal injuries, is Thompson v. Thompson, ${ }^{45}$ decided by the Federal Supreme Court in 1910. That was an action for assault and battery. The District of Columbia statute, which the court was construing, provided that "married women shall have power to engage in any business, and to contract, whether engaged in business or not, and to sue separately upon their contracts, and for torts committed against them, as fully and freely as if they were unmarried."46 The majority opimion, written by Mr. Justice Day, held that if Congress had intended that the wife should have power to sue the husband in tort for personal injuries, "it would have been easy to have expressed that intent in terms of irresistible clearness," and that

22 (1916) 124 Ark. 167, 186 S. W. 832 . In Brown v. Brown (1914) 89 Atl. 889 (Conn.), the Supreme Court of Errors of Connecticut permitted the wife to recover damages from her husband for assault and battery and false imprisonment. The statute provided in effect that each party to a marriage relation retained his or her legal identity, capacity of owning property separately, power of contracting, and each might sue or be sued separately. The court based its decision on the ground that the injury to her person, inflicted by the husband, gave rise to a chose in action, which was property belonging to her for which she could maintain an action. Cf. Prosser v. Prosser, supra.

49 (1890) 53 Ark. 117, 13 S. W. 801.

41 Acts, 1915 , \& 1, p. 684.

45 (1910) 218 U. S. 611, 31 Sup. Ct. 111, 54 L. Ed. 1180.

1631 Stat. at L. 1374, ch. 854, \& 1155. 
the wife had an adequate remedy in the criminal courts, or under the statutes for divorce and alimony. The court was further. of the opinion that to permit the wife to sue the husband in this action "would open the doors of the courts to accusations of all sorts of one spouse against the other, and bring into public notice complaints for assault, slander, and libel, and allegel injuries ... by husband against wife, or wife against husband." $4 \tau$

The dissenting opinion in Thompson $\mathrm{v}$. Thompson, supra, written by Mr. Justice Harlan, concurred in by Justices Hughes and Holmes, took the ground that it was no concern of the judiciary that the policy or conception of justice of the legislative branch of government was different from the individual views of the justices; and that to adopt the construction of the majority would lead to the inconsistent result of permitting the wife to sue the husband for torts to her property, which the statute permitted, but not be permitted to sue him for torts to her person. ${ }^{48}$ Whatever view, however, the Federal Supreme Court would take under a

${ }^{4 \pi} \mathrm{Cf}$. the language of Mr. Justice Peters, in Abbott v. Abbott (1877) 67 Maine, 304: "If such a cause of action exists, others do. If the wife can sue the husband, he can sue her. If an assault was actionable, then would slander and libel and other torts be. Instead of settling, a divorce would very much unsettle all matters between married parties. The private matters of the whole period of married existence might be exposed by suits. The statute of limitations could not cut off actions, because during coverture the statute would not run."

${ }^{48}$ In general, it may be said that the jurisdictions which deny the wife power to sue the husband in tort are governed by emancipation statutes not as liberal as in the cases heretofore discussed. In one class of cases, married women are permitted to maintain suits on contracts and property rights the same as the husband, and these statutes have generally been construed to give no greater rights than the husband himself had. Such are the cases of Strom v. Strom (1906) 98 Minn. 427, 107 N. W. 1047 (action after divorce for assault during coverture); Schultz v. Christopher (1911) 65 Wash. 496, $118 \mathrm{Pac}$. 629 (action after divorce for infection from venereal disease incurred during coverture); Drum v. Drum (1903) 69 N. J. Law 567, 55 At1. 86; Rogers v. Rogers (1915) 177 S. W. (Mo.) 382 (action for false imprisonment for confinimg wife in insane asylum). Another type of statutes empower the wife to contract and to hold property as if she were single, and provide she may sue and be sued in the same manner. Courts under such statute have construed her powers to sue or be sued as belonging exclusively either to contract or property rights and obligations. See Bandfield v. Bandfield (1898) 117 Mich. 80, 75 N. W. 287; Main v. Main (1892) 46 I11. App. 106; Peters v. Peters (1909) $156 \mathrm{Cal}$. 32, 103 Pac. 219. A third type of statute gives the wife power over her property the same as if she were unmarried. Here some courts refuse to give her a general tort action against her husband. Lillienkamp v. Rippetoe (1915) 179 S. W. (Tenn.) 628; other courts give her a tort action against her husband involving her property, but refuse to permit a tort action for personal injuries. Carpenter v. Carpenter (1908) 154 Mich. 100, 117 N. W. 598; Smith v. Smith (1898) 20 R. I. 556, 40 Atl. 417 ; Cartey v. Gleissner (1885) 62 Wis. 493; Wood v. Wood (1881) 83 N. Y. 575. The New York courts, under a statute authorizing the wife to maintain an action in her own name against any person for 
more liberal statute with reference to the wife suing the husband in tort, is of course not to be decided by the case of Thompson v. Thompson; and it must furthermore be borne in mind that this case is confined to the single issue whether the wife may sue the husband for personal injuries, and is not on the question of tort actions for damages to her property.

In view of this diversity of authority on the general question of tort actions by the wife against the husband-regardless of the fact that the general tendency is toward greater liberality by the courts-what should be the rule were a court to have a case of first impression arising before it? Should all tort actions be allowed, serious as well as trivial? Should any tort actions be allowed at all? To answer these questions, a number of points must be taken under advisement.

1. It is suggested that to allow the wife to recover for personal injuries or other torts inflicted by the husband would be to open the door to every conceivable species of fraud, deception, and perjury, through which designing women would be enabled to go into courts and recover for alleged wrongs which they had never sustained. ${ }^{49}$ But the answer to this contention is that the divorce courts open the same avenues in order to recover undeserved alimony.

2. Furthermore, the argument has also been advanced that to permit one spouse to maintain an action for tort against the other during coverture would be to invade the holy sanctity of the home, giving rise to family discord, and perhaps lead to its disruption. But the obvious answer is that the wrong might never have occurred had a tort action been imminent in the knowledge of the wrongful party; and fear of the notoriety attendant upon such action would restrain rather than foster domestic discord. Moreover, with the policy, expediency, or wisdom of legislation, where a statute clearly gives the wife power to sue the husband in tort, the judiciary should have no concern..$^{50}$

an injury to her person or character, as if she were sole, have denied her any relief against her husband for battery or slander. Longendyke v. Longendyke (1863) 44 Barb. (N. Y.) 366.

49 Longendyke v. Longendyke, supra, n. 48.

50 "If that result [of the wife suing the husband in tort for personal injury] be undesirable on grounds of public policy, it is not within the functions of the court to ward off the dangers feared or the evils threatened simply by a judicial construction that will defeat the plainly expressed will of the legislative department. With the mere policy, expediency, or justice of legislation, the courts, in our system of government, have no rightful concern." Mr. Justice Harlan, dissenting in Thonipson v. Thompson, supra. 
3. Many courts permit the wife to sue the husband wherever her property or contract rights are involved. ${ }^{51}$ It is difficult, therefore, to understand why the wife may not bring a tort action against the husband where a greater right-the right of physical integrity, in some instances-is involved. It would seem, on the reasoning that public policy forbids the wife to sue the husband, that these courts have read into the law a purely personal exception for which, both in analysis and logic, there is no warrant or authority. ${ }^{\text {s2 }}$

4. It is maintained by those courts which deny, a tort action, for personal injuries at least inflicted by the husband, that the wife has a remedy against him by a bill of divorce. The answer to this is that often a divorce may not be adequate by way of compensation for damages, ${ }^{53}$ a statute may not grant one under the circumstances, and religious scruples may, on the part of the wife, prevent her attempting to secure one. And in the absence of an express statute saving the right of dower, this interest may be cut off. ${ }^{54}$

5. Under those statutes which are construed by the courts to permit the wife to sue the husband regarding her property, but deny tort actions committed by him on her person, or other grievous wrongs, it is submitted that analytically an unsound distinction has been made by them; for, as analyzed by some of the more liberal courts, her right of action against her husband is really a property right, a chose in action, which she inay reduce to possession..$^{55}$ And as the court in Brown v. Brown, supra,

51 See note 46, supra.

62 Cf. the language of Mr. Justice Harrison, in Fiedeer v. Fiedeer, supra: "Yet those very decisions [refusing a wife relief in tort against her husband], in support of their philosophy, hold that the civil courts are open to parties seeking divorce and alimony, and that the criminal courts are open for the prosecution of either husband or wife for assault and battery, cudgelings, or for shooting each other with shotguns. We fail to see the force of this philosophy."

${ }^{53} \mathrm{Mr}$ Justice Sayre, in Johnson v. Johnson, supra, said: "The wife's remedies, by a criminal prosecution, or an action for divorce and alimony, which in some jurisdictions are allowed to stand as her adequate remedies for wrongs of the sort described in this complaint (assault and battery), so far from being adequate remedies, appear to us to be illusory and inadequate."

54 In Barrett v. Vailing (1884) 111 U. S. 523, the Federal Supreme Court held that, in the absence of a statute saving it, a divorce from the bond of matrimony, for fault of the husband, barred the wife's right of dower.

55 In Brown v. Brown, supra, n. 42, the court in discussing the nature of the wife's claim against the husband for torts committed by him against her, said: "Such a tort gives rise to a claim for damages. Such claim is property" 
pertinently inquires, "If the wife may sue for a broken promise, why may she not sue for a broken arm?"

6. The suggestion that the husband, for a grievous wrongful or felonious assault on his wife, could be indicted under the criminal law, and that for this reason the wife should not be permitted to sue him in a civil action, may work out injustice in a concrete case. The conviction of the husband would be no reparation, at least financially, to the wife, particularly if she had been so seriously crippled that her earning capacity had been permanently impaired; and if the husband were, as a result of the criminal indictment, sent to prison, the wife would not benefit by the husband's legal duty to support her, but would be thrown upon her own resources.

7. When the reason for a legal rule ceases, the rule itself should no longer be kept in force (cessante ratione, cessat lex). The notion that the wife could not bring a tort action against the husband was, as is well known, based partly upon the idca that the husband and wife were a legal unity, and also upon the further theory, an inference drawn by courts in a barbarous age, that the wife was a mere chattel, and hence without any right of property or person. The beneficent legislation, beginning with the middie of the nineteenth century, sought to create a fundamentally new status for the married woman, and if the courts had, as a rule, recognized this revolution in the law, and given effect to it in their decisions, our law on this matter would not have been in such discord. But the courts, under the conception that common law incapacities were natural ones, and that the legislature really could not have meant to do the impossible-to change these inherited incapacities-read into these liberal statutes decidedly illiberal results. To the praise of some courts, under the controlling influence of former illiberal precedents, it must be said that they deprecate the fact that they are thus bound. ${ }^{58}$ And

not in her possession, but which she may by action reduce into possession, just as she might before her coverture have had an action against him for such a tort committed before that event. The husband's delict, whether a breach of contract or personal injury, gives her a cause of action. Both necessarily follow from the fact that a married woman now retains her legal identity and all her property, both that which she possessed at the time of marriage, and that acquired afterward."

${ }_{56}$ The logic of permitting the wife to maintain tort actions against her husband, which, however, is prevented by precedents to the contrary, makes a strong appeal to some courts. In Sykes v. Speer (1908) 112 S. W. (Tex. Civ. App.) 422, the court says: "It would seem to the writer that, if a husband can be held responsible criminally for unjustifiable assault upon one 
as already pointed out, other courts are decidedly breaking with the past, and reaching results in consonance with the emancipatory legislation regarding married women.

It has been suggested, therefore, that it would not be socially undesirable if, in harmony with the declared will of the legislative branch, the wife were given a general remedy in tort against the wrongful acts of her husband. So long as the parties to the marriage relation live in domestic tranquillity, and there is left that affection and respect which alone make a true marriage possible, the bringing of tort actions against one another will be improbable, if not impossible. That the possibility of a suit by one of the spouses against the other exists, has already been shown to be a deterrent to the wrongful acts of the other party. Courts are established to give to parties a rational method of peaceably settling disputes, and to preclude self-help in the enforcement or exercise of rights, or the abusive exercise of powers and privileges. A fortiori, if a serious tort has been committed by one spouse against the other, and then the marriage relation is terminated, there should be no scruples by the courts to permit a tort action, especially where the injury is a lasting and permanent one. $^{57}$ Here again, in torts committed against the wife, the solicitude of the law, in the absence of strong countervailing social interests, should be in the injury which has been perpetrated, and not the character of the wrongful party.

\section{Tort Actions Against Municipalities}

In recent times, municipalities have more and more entered into those phases of industrial activity which heretofore were confined to private individuals alone; from a policy of laissez faire, inherited from Adam Smith and Ricardo in economics, and John

whom the law has placed under his care and protection, and who has for his sake surrendered so many of her civil rights and given up the legal status which she otherwise might sustain, certainly the same considerations of policy would permit her to recover compensation for damages which his brutality may have inflicted upon her, when sought in a proceeding after the dissolution of the marriage relation. But the holdings of the courts which we are compelled to follow have adjudged otherwise, and our duty is plain."

${ }_{57} \mathrm{Cf}$. the language of Mr. Justice Thayer, in Brown v. Brown, supra, n. 42: "When the purposes of the marriage relation have wholly failed by reason of the misconduct of one or both of the parties, there is no reason why the husband or wife should not have the same remedies for injuries inflicted by the other spouse which the courts would give them against other persons. Courts are established and maintained to enforce femedies for every wrong upon the theory that it is for the public interest that personal differences should thus be adjusted rather than that the parties should be left to settle them according to the law of nature." 
Stuart Mill and Bentham and Spencer in politics, we have entered upon a period of paternalism in government. The marked increase in commissions of all kinds bears witness to changed theories and economic conditions. Constitutions have given to cities power to become, in actual fact, gigantic public service corporations in conflict with private initiative, owning and operating gas and electric companies, establishing and maintaining street railways, and supplying citizens with coal and other necessities of life. Anciently, the city performed but few of these functions; its activity was largely negative, not positive, confined to governmental acts and not engaged in ordinary business. As a consequence, the rules of law as to tort liability of municipalities became colored or crystallized under different conditions, and we have inherited these doctrines today. In the present the great problem with reference to the liability of cities is whether changed conditions do not require modification of the old doctrines as to tort liability, and particularly as these are based upon the so-called separation between governmental and corporate functions. If this distinction is now not valid, but should be abandoned, we have taken a long step forward, in the absence of opposing social interests, in holding the city to tort liability in general.

Recently; in Fowler v. City of Cleveland, ${ }^{58}$ the Supreme Court of Ohio overthrew the old distinction between governmental and corporate activities of municipalities, and granted relief in a tort action on the same basis as if the city had been a public service corporation. In that case, plaintiff's intestate was killed through the negligent operation, by defendant's servant, of a motor-truck belonging to the city fire department when operated at a high rate of speed, apparently not answering an emergency fire call. The court, Mr. Justice Johnson delivering the opinion, criticising the old notion of a distinction between governmental or public and corporate or private functions of cities, said:

"Now the activities and undertakings of a municipal corporation are manifold. They reach and touch in countless directions. It seems to be utterly unreasonable that all these activities and enterprises which are brought closely home to the lives of all of the people of the municipality must still be regarded as bound up in the vague and uncertain sphere of what is called a governmental function." (p. 74.)

That the Fowler case is revolutionary as to tort liability of

58126 N. E. (Ohio) 72, decided in 1919. 
municipal corporations, is pointed out by the dissenting opinion in these words:

"The decision in this case not only overrules the established legal principles heretofore announced by this court, but is at variance with the principles settled by practically every court in this country." (p. 79.)

The Federal Supreme Court has likewise questioned the old distinction between private and governmental functions of municipalities. In 1900 it decided, by a five to four decision, the case of Workman v. New York City. ${ }^{59}$ In that case, plaintiff filed a libel in personam in an admiralty court, against the City of New York, to recover for loss caused by the wrongful, negligent act of one of the city's fireboats, while it was attempting to reach a fire alongside the wharf. While it was conceded that the local law of New York would not permit recovery, because of the old distinction between governmental and corporate functions, yet recovery was allowed in the admiralty court. Mr. Justice White, in delivering the majority opinion, said:

"Because we conclude that the rule of the local law in the State of New York ... does not control the maritime law, and therefore affords no ground for sustaining the nonliability of the City of New York in the case at bar, we must not be understood as conceding the correctness of the doctrine by which a municipal corporation, as to the discharge of its administrative duties, is treated as having two distinct capacities, the one private or corporate and the other governmental or sovereign, in which latter it may inflict a direct and positive wrong upon the person or property of a citizen without power in the courts to afford redress for such wrong. . . . And although this opinion is confined to the controlling effect of the admiralty law, we do not intend to intimate the belief that the common law, which benignly above all considers the rights of the individual, yet gives its sanction to a principle which denies the duty of courts to protect the rights of the individual in a case where they have jurisdiction to da so." (p. 220 of 21 Sup. Ct., p. 573 of 179 U. S.)

The rule as laid down above by the Federal Suprenie Court is apparently well settled in the admiralty courts in this country. ${ }^{60}$ If it can be applied in admiralty, why not in the common-law courts? The only answer that can really be vouchsafed is one based upon historieal legal practices, rather than one based upon

59 (1900) 179 U. S. 552, 21 Sup. Ct. 212, 46 L. Ed. 314.

${ }^{60}$ City of Chicago v. White Transportation Co. (1917) 243 Fed. 358; City of Chicago v. Chicago Transportation Co. (1915) 222 Fed. 238. 
all the various individual and social interests involved, or upon any analytically sound distinction. At common law, the reason why suits, at least for the omission of public duties (nonfeasance), did not lie generally against towns and cities was that no action on the case was permitted to the private individual, the proper remedy being by indictment. ${ }^{81}$ Later, the courts, in holding that a private individual had no action against a town, placed this upon the ground that it was because cities were not corporations ; ${ }^{: 2}$ and thereafter, both in England and America, no recovery was allowed largely because of the decided precedents. ${ }^{63}$ No attempt was made until somewhat later to draw any distinction, so far as cities were concerned, between nonfeasance in public duties (failure to act at all) and misfeasance (acting but acting unlawfully). Whether such distinction ought not to be made, will be considered presently.

When investigation is made of the actual decisions themselves, denying recovery against municipalities where they have acted unlawfully (misfeasance) in the performance of so-called governmental duties, we find a variety of reasons given by the courts for the justification of such a doctrine-another example of the way in which apocryphal reasons are put behind legal rules when. the conditions or reasons which called them forth ceased to exist. Note the following : ${ }^{8 t}$

"Five reasons have, at one time or another, been given: 1. The state is sovereign and the municipality its governmental agency: no suit can be brought against the state without its consent, therefore none against the municipality. 2. The municipality derives no pecuniary benefit or profit from the exercise of public functions. 3. Members of municipal departments in the exercise of public duties are not agents of the city, therefore the doctrine of respondeat superior has no application. 4. It is necessary for the proper performance of governmental functions that a municipal corporation should not be liable for the negligence of its servants. 5. Municipalities should not be liable for torts committed in the performance of duties voluntarily assumed under general statutes." None of the distinctions taken by the courts, as mentioned

61 Bro. Abr., Accion sur le case, pl. 93.

62 Thomas v. Sorrell (1706) Vaugh. 330, 340.

B3 Bartlett v. Crozier (1820) 17 Johns. (N. Y.) 439; Mower v. Leicester (1812) 9 Mass. 237; Russell v. Men of Devon (1788) 2 T. R. 667 .

o4 Note, Tort Liability of Municipal Corporations, 34 Harvard Law Review, 66, 67 . 
above, will bear the test of analysis so far as the general principles of torts and agency are concerned. Tort liability is not imposed because of any benefit which the wrongdoer receives; nor is the municipality sovereign in the same sense that the state, which created it, is; and respondeat superior depends upon the degree of control which the principal exercises, whether there is the relation of independent contractor or not; and voluntary assumption of duties has never been the criterion of tort liability; and lastly, proper performance of public duties rests upon broader grounds than merely that the city's agents or servants should be immune from tort liability for neglect acts. It is difficult to see why, therefore, the principles of legal liability should not be applied to cities equally well as in the case of private corporations, so long as no countervailing social interests prohibit this.

Furthermore, the decisions, in American jurisdictions at least, are by no means uniform or consistent as to exactly what is and is not a governmental function. In Hibbard v. City of Wichita, ${ }^{65}$ plaintiff, while leaning against a coyote cage in the zoological park maintained by the City of Wichita, was bitten and scratched by the coyote. The court, while recognizing that in other jurisdictions maintenance of such parks was not a governmental function, nevertheless decided that such was not the rule in Kansas, and therefore denied recovery. ${ }^{68}$ Similarly with respect to other functions of municipalities-as operation of fire departments, elevators in city halls, driving ambulances, sweeping and cleaning streets, street lighting, maintaining prisons, and health departments-the decisions show a divergence of opimion. ${ }^{67}$

On principle, apart from authoritative precedents, what should be the rule with respect to tort liability of municipalities? It is submitted that, in general, tort liability should be imposed upon the city just as upon a private corporation or private citizens, except where there are certain justifications, based on strong countervailing social interests, which excuse or exempt the city

65 (1916) 98 Kan. 498, 159 Pac. 399. A case asserting that maintenance of parks is not generally a governmental function is Gartland v. New York Zoological Society (1909) 135 App. Div. 163, 120 N. Y. Supp. 24.

66 In the Gartland case, supra, the court said: "Its duty in regard to the condition of its streets and its parks and public places is not governmental, so that it is relieved from responsibility for negligence." (P. 30.) Cf. Weber v. Harrisburg (1906) $216 \mathrm{~Pa}$. St. 117, 64 Atl. 905; Clark v. Inhabitants of Waltham (1880) 128 Mass. 567. 1742.

674 Dillon, Municipal Corporations, 5th ed., $\$ \$ 1656,1658,1687,1708,1741$, 
from the legal consequences of its acts. Here again, as in other fields, it is the injury to the individual which should be of paramount and primary consideration, not the character of the party who causes it. Today we are seeking to distribute the human waste, including injuries received, believing that the social group can bear the loss much better than the poor, unfortunate individual. This is true in workınen's compensation laws, minimum wage legislation, sickness, old age and accident insurance, and laws restricting public utilities to reasonable rates and reasonable service. The municipal corporation, an organization of part of the social group, should not escape its just share of this burden to society at large.

Several different situations may be noticed with respect to imposing tort liability upon the municipality:

1. For the omission of certain public functions, obviously the city should not be held liable to private individuals, unless these can show a violation of some legal duty running to themselves. The law does not impose the standard of the Good Samaritana purely moral standard-upon either private individuals or public corporations; in other words, where there is no relation subsisting between the parties, no principle of tort liability can be invoked. ${ }^{88}$

2. In cases of affirmative conduct on the part of the city there should be liability on the city, in the absence of strong social interests against it, according to the general principle of torts in such cases. If a city has undertaken to act, and may lawfully act, it should be held for having acted in an unlawful manner (misfeasance); and this is the rule generally in torts where the defendant is a private individual or private corporation. ${ }^{69}$

68 So in Union Pac. Ry. Co. v. Cappier (1903) 66 Kan. 649, 72 Pac. 281, the omission of railway employees, after having struck a trespasser on a railway track, to take care of him and give him medical attention, was held not to be actionable. On the general principle of relation in the common law, imposing duties where otherwise the law would not give a remedy, see Roscoe Pound, "The End of Law as Developed in Juristic Thought," 30 Harvard Law Review, 201, 211 et seq.

69 So defendant railway was held liable where its employees, in assisting an intoxicated passenger from the train, failed to do that which ordinary, reasonable men under similar circumstances would have done, Black v. New York, N. H. \& H. Ry. (1907) 193 Mass. 448, 79 N. E. 797. See also Depue v. Flateau (1907) 100 Minn. 299, 111 N. W. 1, defendant held liable to invitee in compelling him, when ill, to leave defendant's premises and be exposed to the elements; Hunicke v. Meramec Quarry Co. (1914) 262 Mo. 560, 172 S. W. 43, defendant employer held liable for failure to secure medical care for injured employee. 
So in Rochester White Lead Company v. The City of Rochester, ${ }^{70}$ the city was held liable where it had unskilfully contructed a certain culvert for draining off water, so that because of a freshet occurring plaintiff's land and factory were flooded. There may be instances, however, where the affirmative acts of the city and its servants or agents may be exempted from legal liability because of strong countervailing social interests. There is the social interest in the maintenance of law and order, and consequently the private individual ought not to be permitted to bring a tort action against the city for unlawful acts committed by the police. ${ }^{71}$ Then again, there is the social interest in the protection of property and the lives of others; hence, when engaged in the duty of sending fire engines to the scene of the fire as quickly as possible, the city should not be held liable in a private action for torts committed on private parties. ${ }^{2}$

3. What should be the rule with respect to torts arising from property ownership on the part of the municipality? Is there any ground here also for holding the city immune from the general principles of tort liability applicable to private individuals and private corporations? Already injuries received, or damage caused, from sewers and streets give rise to actions against cities in tort, in the majority of jurisdictions. ${ }^{73}$ These instances have admittedly been treated as exceptions. It is subinitted, however, that to be consistent the city should be likewise held liable for most cases arising from property ownership $;^{74}$ for the very ownership and use of property involves a relation or duty to the outside or external world. Some courts have laid down the criterion that liability will be imposed wherever the property owned by the city is either wholly or partially used for gain or profit to the city. So, to take a commonly cited case, if part of a city hall, for instance, is rented, while the other part is used for municipal purposes, there will be liability in tort; but if all the building is

70 (1850) 3 N. Y. 463.

71 Lamont v. Stavanaugh (1915) 129 Minn. 321, 152 N. W. 720, city exempted from liability for assault committed by one of its police officers known by it to have violent and savage propensities. See also Woodhull v. City of New York (1896) 44 N. E. 1038; Coley v. City of Statesville (1897) 28 S. E. 582; McIlhenney v. City of Wilmington (1900) 37 S. E. 187; Craig v. City of Charleston (1899) 54 N. E. 184.

72 Opocensky v. City of South Omaha (1917) 101 Neb. 336, 163 N. W. 325 , city liable for injury caused by operating motor vehicle at excessive speed when not answering emergency call.

734 Dillon, Municipal Corporations, \$\$1741, 1742.

74 Jones, Negligence of Muricipal Corporations, 36. 
used for municipal purposes no liability attaches. ${ }^{75}$ But often the benefit or profit test is not a sound one, for unless a net profit is made it can hardly be said that tort claims arising out of the making of the profit may be reimbursed from this source. Furthermore, usually the profit is distributed to the benefit of the community at large anyway, leaving no surplus to be distributed to settling tort claims. ${ }^{76}$ The city's employees, who are obligated to look after the property of the city, will be incited to greater efficiency and care if it be known that tort actions may possibly be brought as a result of injury or damage sustained. So if a workman were injured because of the dangerous condition of a fire engine, or for building a cistern for the use of the city; or if plaintiff was damaged by reason. of trespasses committed by the fire horse which was permitted negligently to escape from its stable, there ought to be liability imposed on the city, solely because of its ownership of property. ${ }^{77}$ That the law has not gone thus far is of course admitted; but to bring logic and consistency into the law governing tort liability of cities is certainly a crying need of the times.

\section{Tort Actions for Nervous Shock and Mentax Suffering}

In the history of the law, both Roman and common, injuries to the body are the first torts dealt with besides those to property. Injury to the nervous system, to the sensibilities, and overcoming the will are not recognized until considerably later, and then with many qualifications. Difficulties of proof of the injury, inadequacy of the legal system, and possibilities of fraud, have required the law to proceed cautiously with reference to these intangible interests. ${ }^{78}$

Until comparatively recent times the prevailing doctrine in America with reference to tort actions for mental or nervous shock resulting in physical injury was against relief, the primcipal

75 Worden v. City of New Bedford (1881), 131 Mass. 23, 41 Am. Rep. 185; Little v. Holyoke (1900) 177 Mass. 114, 58 N. E. 170; Kelly v. City of Boston (1908) 186 Mass. 165, 71 N. E. 299.

${ }^{76}$ See note, Municipal Liability for Tort, 30 Harvard Law Review, 270, 271 et seq.

77 City of Lafayette v. Allen (1881) 81 Ind. 166 (workman injured by fire engine); Mulcairns v. City of Janesville (1886) 67 Wis. 24, $29 \mathrm{~N}$. W. 565 (negligence in building a cistern for city); Cunningham v. City of Seattle (1905) 40 Wasl. 59, 82 Pac. 143 (trespass by horse).

78 Roscoe Pound, "Interests of Personality," 28 Harvard Law Review, 343, 361. 
case being Spade v. Lynn \& Boston Ry. Co. in Massachusetts. ${ }^{79}$ Moreover, on the question of nervous shock resulting in physical injury the authorities are still somewhat at variance, although an increasing number of jurisdictions are permitting recovery even where the wrongful act was only negligent and not intentional. ${ }^{80}$ The doctrine seems well settled in England, Ireland, and Scotland. ${ }^{81}$ Even in those jurisdictions where no recovery is permitted for negligent acts, relief will be granted where the defendant intentionally sought to injure plaintiff. ${ }^{82}$ And where defendant uses threatening words, which in themselves amount to a tort, he will be liable for any nervous illness resulting proximately. So also, threats of bodily harm sent by letter, and resulting in illness because of fear of violence, have been held to be ground for an action. ${ }^{83}$

Recently, however, we ineet a few decisions which seem to grant a tort action where no physical injury has itself occurred, but where only inental anguish or suffering is proved. A striking case is Nickerson v. Hodges, ${ }^{84}$ decided in Louisiana in 1920 . In that case there was a tradition in the neighborhood that an ancestral pot of gold was buried nearby. A colored fortune-teller showed plaintiff a map of the supposed treasure, and plaintiff began to dig for gold. Defendants as a practical joke hid a sealed pail filled with rocks and dirt in a place where plaintiff would inevitably unearth it. She found the pail and, in accordance with instructions contained in a note inside, solemnly opened

79 (1897) 168 Mass. 285, 47 N. E. 88. In accord: Mitchell v. Rochester Ry. (1896) 151 N. Y. 107,45 N. E. 354; Nelson v. Crawford (1900) 122 Mich. 466,81 N. W. 335.

80 Throckmorton, "Damages for Fright," 32 Harvard Law Review, 260, 265 , and cases there cited.

81 The leading case is Dulieu v. White \& Sons [1901] 2 K. B. 669 . Plaintiff, a woman, was standing behind the bar of the public house operated by her husband. Defendant's servant negligently drove a pair of horses and van into the house, frightening plaintiff, and miscarriage resulted. The court in granting relief expressly overruled Victorian Railway Comrs. v. Coultas (1888) 13 A. C. 222. See Throckmorton, supra, for Scotch and Irish decisions.

82 In Jeppsen v. Jensen (1916) 47 Utah, 536, 155 Pac. 429, defendant pointed a pistol at plaintiff's husband, threatening to kill him; recovery was granted plaintiff wife for the mental anguish resulting in physical injury. See also Davidson v. Lee (1911) 139 S. W. 904 (Tex. Civ. App.).

${ }^{83}$ Lonergan v. Small (1909) 81 Kan. 48, 105 Pac. 27 (assault); Engle v. Simmons (1906) 148 Ala. 92, 41 So. 1023 (trespass); Garrison v. Sun. Pub. Assn. (1912) 207 N. Y. 1, 100 N. E. 430 (slander). Threats of bodily harm sent by letter, resulting in illness: Grimves v. Gates (1874) 47 Vt. 594; Houston v. Woolley (1889) 37 Mo. App. 15.

84 (1920) 84 So. 37 (Louisiana). 
it in the presence of all the heirs. On learning of the joke, her rage and mental anguish over disappointed hopes were excessive. She had been insane before, and this disappointment aggravated her case, although this was not emphasized in the trial. She died pendente lite, but the Supreme Court of Louisiana, under a statute passing rights of action of deceased, gave relief. The court, Mr. Justice Dawkins delivering the opinion, said: "If Miss Nickerson were still living, we should be disposed to award her damages in a substantial sum."

A recent case in England ${ }^{85}$ reached a similar result, although here the plaintiff became seriously ill, so that the case does not turn exclusively on nervous shock or mental anguish. In that case defendant, who was a private detective, in order to induce plaintiff to divulge information contained in some letters, said to her, "I am from Scotland Yard. You are the woman we are after. You have been corresponding with a German spy." The case was decided in harmony with a similar previous case in England. ${ }^{86}$ And an increasing number of courts in America have permitted recovery for mental anguish purely, wherever they could find that some other more substantial right had been violated, so that recovery might be allowed as ancillary to the main action. In Nordgren v. Lawrence, ${ }^{87}$ decided by the Supreine Court of Washington, plaintiff's landlord wrongfully entered the premises, which plaintiff held from month to month, and frightened her badly, although no physical injury was proved. In an action for the wrongful entry, plaintiff was permitted to recover for her mental suffering also. A number of other courts have given relief for mental suffering alone, apart from physical injury, as ancillary to the main proceeding. ${ }^{88}$ The reasoning of the courts who grant relief in this fashion is based upon the view that otherwise groundless or fraudulent suits would be brought, resulting in using the law for purposes of imposture. This is undoubtedly a sound

85 Janvier v. Sweeney and Barker [1919] 2 K. B. 316.

86 Wilkinson v. Downton [1897] 2 Q. B. 57; Bielitzki v. Obadisk (1921) 3 W. W. Rep. 229 (K. B., Sask.).

87 (1913) 133 Pac. 436 (Wash.)

88 Tenn. Cent. Ry. Co. v. Brasher's Guardian (1906): 97 S. W. 349, recovery allowed for mental suffering because of mistake of railway crew in putting plaintiff off at wrong station; Davis v. Tacoma Ry. \& Power Co. (1904) 77 Pac. 209 (Wash.); damages given for mental suffering for wrongfully ejecting plaintiff who was thought to be some notorious character; Larson v. Chase (1891) 47 Minn. 307, 5G N. W. 238, recovery for mental anguish where defendant had wrongfully mutilated and dissected body of plaintiff's deceased husband. 
reason in many instances; but it is submitted that if no fraud is present, and mental suffering is clearly proved, recovery ought to be permitted even though no other right has been at the same time violated. Cases might conceivably arise where severe mental shock was occasioned to two parties, and one would be allowed to recover simply because technically some other right had been violated for which he could bring a proceeding in court. As for example, if $\mathrm{A}$ is present at B's home as a guest, and $\mathrm{C}$ negligently causes an explosion on his own land, resulting in casting rocks upon B's land. Here B could recover for the mental suffering because there was technically a trespass to his land, and this main action would give him standing in court; but $A$ would be without remedy unless he could show physical damage at the same time, and even then he would be running risks, dependent on the viewpoint of the particular jurisdiction in which he might be, as to whether he would be given relief.

However, in the decisions which grant damages for purely mental suffering apart from physical injury wherever some other more substantial right has been violated, one sees apparently' a conscious attempt on the part of courts to enlarge the sphere of interests which the law should recognize and protect. That this recoguition must be given cautiously, in view of the large opportunities for fraud and imposture liable to be practiced upon courts, goes without saying; but the viewpoint should be that, if injury has actually been proved, even though it lias been difficult to do so, the law should give a remedy if at the same time there are no strong countervailing social interests which would prohibit it. On the other hand, obviously not every case of inental suffering can be given relief by the judicial machinery; the limits of effective legal action may preclude it. For example, the common law has never yet, at least in a separate tort action, given a remedy for overcoming of another's will-his interest in the free use of his mental activities-although the Roman Law for centuries, in the actio quod metus causa, did recognize and protect such interest, quite apart from the praetor's setting aside, in a restitutio in integrum, transactions entered into in such manner. ${ }^{89}$

$89 \mathrm{It}$ is asserted by modern authorities, though it is doubtful, that a person might bring the actio metus causa and also obtain restitution. Essentially the actio metus causa was rei persecutoria and the formula was always couched in the alternative, so that the defendant could relieve himself from the penalty by restoring what had been improperly obtained from the plaintiff. Professor Radin states that the pure delict of metus would be actionable 
Moreover, in the common law, besides the difficulties of proof, or fraud and imposture, and the method of proof by jury, the question of the standard of duress, or overcoming of the will, has likewise complicated matters. While originally, in both the Roman and the common law this was much easier-the standard being objective and the peril being of life or limb, and imprisonment ${ }^{90}$ the question becomes more difficult wherever the standard of duress becomes a subjective one, as appears to be the tendency today. ${ }^{92}$ The law cannot give relief to the super-sensitive, whether it be on account of overcoming the will, resulting in mental suffering, or for fright and other mental anguish. The law must proceed cautiously, in view of all the individual and social interests involved; but if the viewpoint of the court be that the law should recognize a continually wideming circle of interests, the law will, better than in the past, serve as a means to an end and to the furtherance of civilization.

Western Reserve University,

E. F. Albertsworth.

Franklin T. Backus Law School.

if it could be brought under the following conditions, citing a case from Ulpian (D. Iv. 2, 12, pr.) in which a person was permitted to recover for the fruits that he might have gathered from an estate and which he was prevented by metus from gathering. If this is what Ulpian meant, certainly the common law would have given no action at law for such a case.

80 The change as to the standard of duress in the Roman Law is clearly traceable in the following passages: Code II, 4, 13; Digest IV, 2, 6; Digest IV, 2, 5; Code II, 18, 12; German Civil Code, sec. 123; Japanese Civil Code, sec. 96 .

As to the common law, the same development is seen: 1 B1. Com. 130; 2 Coke. Institutes, 483; Umited States v. Huckabee (1871) 16 Wall. 414, 432;

Galusha v. Sherman (1899) 105 Wis. 263,81 N. W. 495.

"Note, "The Nature and Effect of Duress," 26 Harvard Law Review, 255 ; notes, "Threats to Injure Third Parties," 30 Yale Law Journal, 760. 